Article

\title{
Flexibilins A-C, New Cembrane-Type Diterpenoids from the Formosan Soft Coral, Sinularia flexibilis
}

\section{Li-Chung Hu ${ }^{1,2, \dagger}$, Jui-Hsin Su ${ }^{1,2,3, \dagger}$, Michael Yen-Nan Chiang ${ }^{4}$, Mei-Chin Lu ${ }^{1,2}$, Tsong-Long Hwang ${ }^{5}$, Yung-Husan Chen ${ }^{2}$, Wan-Ping Hu ${ }^{6}$, Nai-Cheng Lin ${ }^{2}$, Wei-Hsien Wang ${ }^{2,3}$, Lee-Shing Fang ${ }^{7}$, Yueh-Hsiung Kuo ${ }^{8, *}$ and Ping-Jyun Sung ${ }^{1,2,3,9, *}$}

1 Graduate Institute of Marine Biotechnology and Department of Life Science and Institute of Biotechnology, National Dong Hwa University, Pingtung 944, Taiwan;

E-Mails: stoja582@gmail.com (L.-C.H.); x2219@nmmba.gov.tw (J.-H.S.); jinx6609@nmmba.gov.tw (M.-C.L.)

2 National Museum of Marine Biology and Aquarium, Pingtung 944, Taiwan;

E-Mails: tony_chen72001@yahoo.com.tw (Y.-H.C.); 1nc7222@hotmail.com (N.-C.L.); whw@nmmba.gov.tw (W.-H.W.)

3 Department of Marine Biotechnology and Resources and Asia-Pacific Ocean Research Center, National Sun Yat-sen University, Kaohsiung 804, Taiwan

4 Department of Chemistry, National Sun Yat-sen University, Kaohsiung 804, Taiwan; E-Mail: michael@mail.nsysu.edu.tw

5 Graduate Institute of Natural Products, Chang Gung University, Taoyuan 333, Taiwan; E-Mail: htl@mail.cgu.edu.tw

6 Department of Biotechnology, Kaohsiung Medical University, Kaohsiung 807, Taiwan; E-Mail: wphu@kmu.edu.tw

7 Department of Sport, Health and Leisure, Cheng Shiu University, Kaohsiung 833, Taiwan; E-Mail: 1sfang@csu.edu.tw

8 Tsuzuki Institute for Traditional Medicine, China Medical University, Taichung 404, Taiwan

9 Graduate Institute of Natural Products, Kaohsiung Medical University, Kaohsiung 807, Taiwan

$\dagger$ These authors contributed equally to this work.

* Authors to whom correspondence should be addressed; E-Mails: kuoyh@mail.cmu.edu.tw (Y.-H.K.); pjsung@nmmba.gov.tw (P.-J.S.); Tel./Fax: +886-4-2207-1693 (Y.-H.K.); Tel.: +886-8-882-5037 (P.-J.S.); Fax: +886-8-882-5087 (P.-J.S.).

Received: 5 March 2013; in revised form: 28 April 2013 / Accepted: 14 May 2013 / Published: 10 June 2013 
Abstract: Three new cembrane-type diterpenoids, flexibilins A-C (1-3), along with a known cembrane, (-)-sandensolide (4), were isolated from the soft coral, Sinularia flexibilis. The structures of cembranes 1-4 were elucidated by spectroscopic methods. The structure of 4, including its absolute stereochemistry, was further confirmed by single-crystal X-ray diffraction analysis. Cembrane $\mathbf{2}$ displayed a moderate inhibitory effect on the release of elastase by human neutrophils.

Keywords: cembrane; diterpenoid; Sinularia flexibilis; elastase

\section{Introduction}

Octocorals, particularly, soft corals belonging to the genus Sinularia, have been demonstrated to be rich sources of bioactive natural products [1,2]. Previous chemical investigations on Sinularia flexibilis, an octocoral distributed widely in the tropical and subtropical waters of the Indo-Pacific Ocean, have yielded a series of interesting cembrane-type diterpenoids [3-20], and most of these compounds have been shown to possess various bioactivities, such as cytotoxic [4,6,11-17,20,21], anti-inflammatory [19,20], neuroprotective [19] and algicidal [9] effects. In continuation of our search for new substances from marine invertebrates collected from the waters of Taiwan, the octocoral Sinularia flexibilis (Quoy and Gaimard, 1833) was studied (Figure 1), as its organic extract was found to display meaningful signals in NMR studies. Three new cembrane-type diterpenoids, flexibilins A-C (1-3), and a known cembrane, (-)-sandensolide (4) [10,22,23], were isolated (Figure 1). In this paper, we reported the isolation, structure determination and bioactivity of cembranes 1-4.

Figure 1. The soft coral, Sinularia flexibilis, and the structures of flexibilins A-C (1-3) and (-)-sandensolide (4).

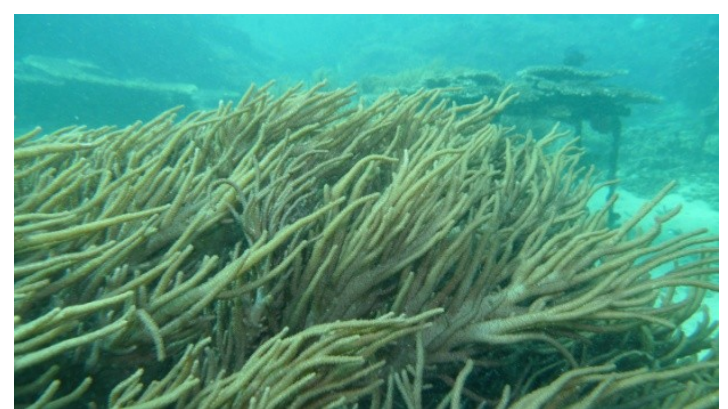

Sinularia flexibilis

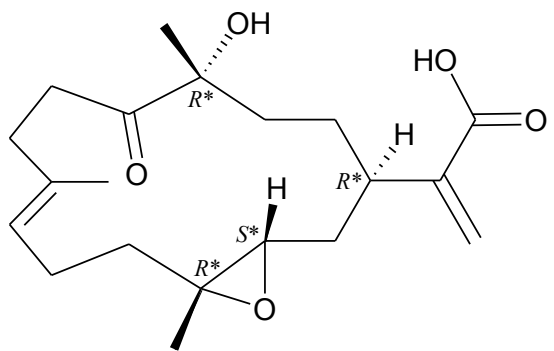

2

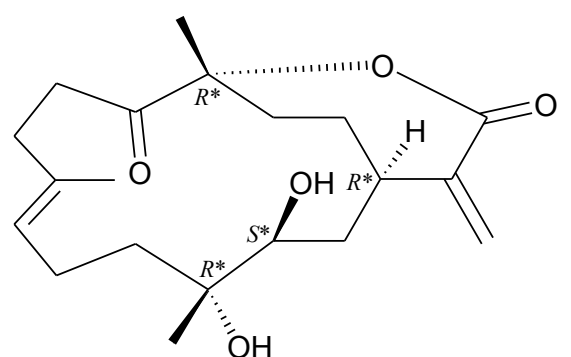

3

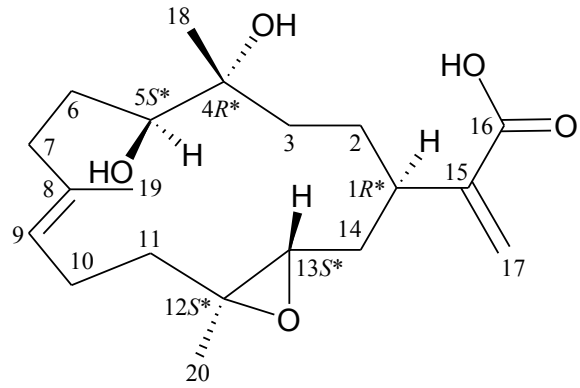

1

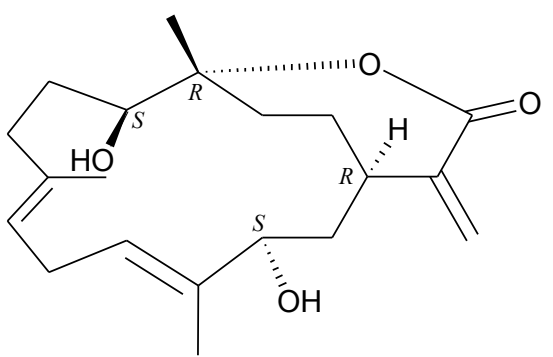

4 


\section{Results and Discussion}

Flexibilin A (1) was obtained as yellowish oil, and its molecular formula, $\mathrm{C}_{20} \mathrm{H}_{32} \mathrm{O}_{5}$, was determined according to a pseudomolecular ion $[\mathrm{M}+\mathrm{Na}]^{+}$at $m / z 375.2144$ (calcd. for $\mathrm{C}_{20} \mathrm{H}_{32} \mathrm{O}_{5} \mathrm{Na}$, 375.2147) identified by HRESIMS, as well as ${ }^{13} \mathrm{C}$ NMR coupled with DEPT spectra (Table 1), which indicated that the double bond equivalence (DBE) of $\mathbf{1}$ was five. The IR spectrum of $\mathbf{1}$ revealed the presence of carboxylic acid, hydroxy and ester functionalities from absorptions at 3750-2400, 3419 and $1711 \mathrm{~cm}^{-1}$, respectively. The ${ }^{13} \mathrm{C}$ NMR data of 1 showed the presence of 20 carbon signals in total, which were assigned by the assistance of the DEPT spectrum to three methyls, seven $\mathrm{sp}^{3}$ methylenes, three $\mathrm{sp}^{3}$ methines, two $\mathrm{sp}^{3}$ quaternary carbons, an $\mathrm{sp}^{2}$ methylene, an $\mathrm{sp}^{2}$ methine and three $\mathrm{sp}^{2}$ quaternary carbons. ${ }^{13} \mathrm{C}$ NMR signals appearing at $\delta_{\mathrm{C}} 170.8(\mathrm{C}-16), 142.7(\mathrm{C}-15)$ and $126.5\left(\mathrm{CH}_{2}-17\right)$ and proton NMR signals appearing at $\delta_{\mathrm{H}} 6.40(1 \mathrm{H}, \mathrm{s})$ and $5.68(1 \mathrm{H}, \mathrm{s})$ suggested the presence of a $\alpha$-exomethylene-carboxylic acid moiety. The main carbon skeleton of $\mathbf{1}$ was elucidated by ${ }^{1} \mathrm{H}-{ }^{1} \mathrm{H}$ COSY and HMBC experiments (Table 1 and Figure 2). From the ${ }^{1} \mathrm{H}-{ }^{1} \mathrm{H}$ COSY spectrum of $\mathbf{1}$, it was possible to establish the separate spin systems of $\mathrm{H}-13 / \mathrm{H}_{2}-14 / \mathrm{H}-1 / \mathrm{H}_{2}-2 / \mathrm{H}_{2}-3, \mathrm{H}-5 / \mathrm{H}_{2}-6 / \mathrm{H}_{2}-7$, $\mathrm{H}-9 / \mathrm{H}_{2}-10 / \mathrm{H}_{2}-11$ and $\mathrm{H}-9 / \mathrm{H}_{3}-19$ (by allylic coupling). These data, together with the key HMBC correlations between protons and quaternary carbons, such as $\mathrm{H}_{2}-2, \mathrm{H}_{2}-3, \mathrm{H}_{2}-6, \mathrm{H}_{3}-18 / \mathrm{C}-4 ; \mathrm{H}_{2}-6, \mathrm{H}_{2}-7$, $\mathrm{H}_{2}-10, \mathrm{H}_{3}-19 / \mathrm{C}-8 ; \mathrm{H}_{2}-10, \mathrm{H}_{2}-11, \mathrm{H}-13, \mathrm{H}_{2}-14, \mathrm{H}_{3}-20 / \mathrm{C}-12 ; \mathrm{H}_{2}-2, \mathrm{H}_{2}-14, \mathrm{H}_{2}-17 / \mathrm{C}-15$; and $\mathrm{H}_{2}-17 / \mathrm{C}-16$, permitted elucidation of the main carbon skeleton of 1 . The tertiary methyls at C-4, C-8 and C-12 were confirmed by HMBC correlations between $\mathrm{H}_{3}-18 / \mathrm{C}-3$, -4, -5; $\mathrm{H}_{3}-19 / \mathrm{C}-7$, -8, -9; and $\mathrm{H}_{3}-20 / \mathrm{C}-11$, $-12,-13$. Thus, from the reported data, the skeleton of $\mathbf{1}$ was identified as a cembrane-type diterpenoid with two rings.

Table 1. ${ }^{1} \mathrm{H}\left(500 \mathrm{MHz}, \mathrm{CDCl}_{3}\right)$ and ${ }^{13} \mathrm{C}\left(125 \mathrm{MHz}, \mathrm{CDCl}_{3}\right) \mathrm{NMR}$ data and ${ }^{1} \mathrm{H}-{ }^{1} \mathrm{H} \mathrm{COSY}$ and HMBC correlations for cembrane $\mathbf{1}$.

\begin{tabular}{clccl}
\hline Position & $\boldsymbol{\delta}_{\mathbf{H}}(\boldsymbol{J}$ in Hz) & $\boldsymbol{\delta}_{\mathbf{C}}$, Multiple & ${ }^{1} \mathbf{H}-{ }^{1} \mathbf{H} \mathbf{C O S Y}$ & $\mathbf{H M B C}$ \\
\hline 1 & $2.70 \mathrm{br} \mathrm{s}$ & $38.1, \mathrm{CH}$ & $\mathrm{H}_{2}-2, \mathrm{H}_{2}-14$ & $\mathrm{C}-13$ \\
2 & $1.63 \mathrm{~m} ; 1.52 \mathrm{~m}$ & $26.6, \mathrm{CH}_{2}$ & $\mathrm{H}-1, \mathrm{H}_{2}-3$ & $\mathrm{C}-1,-4,-14,-15$ \\
3 & $1.60 \mathrm{~m} ; 1.53 \mathrm{~m}$ & $37.1, \mathrm{CH}_{2}$ & $\mathrm{H}_{2}-2$ & $\mathrm{C}-2,-4,-5$ \\
4 & & $74.8, \mathrm{C}$ & & \\
5 & $3.53 \mathrm{~d}(10.0)$ & $74.0, \mathrm{CH}$ & $\mathrm{H}_{2}-6$ & $\mathrm{C}-6,-7,-18$ \\
6 & $1.71 \mathrm{~m} ; 1.59 \mathrm{~m}$ & $28.6, \mathrm{CH}_{2}$ & $\mathrm{H}-5, \mathrm{H}_{2}-7$ & $\mathrm{C}-4,-5,-7,-8$ \\
7 & $2.21 \mathrm{~m} ; 2.14 \mathrm{~m}$ & $33.7, \mathrm{CH}_{2}$ & $\mathrm{H}_{2}-6$ & $\mathrm{C}-5,-6,-8,-9,-19$ \\
8 & & $136.1, \mathrm{C}$ & & \\
9 & $5.11 \mathrm{dd}(6.5,6.5)$ & $122.7, \mathrm{CH}$ & $\mathrm{H}_{2}-10, \mathrm{H}_{3}-19$ & $\mathrm{C}-7,-10,-11,-19$ \\
10 & $2.14 \mathrm{~m}$ & $23.1, \mathrm{CH}_{2}$ & $\mathrm{H}-9, \mathrm{H}_{2}-11$ & $\mathrm{C}-8,-9,-11,-12$ \\
11 & $2.01 \mathrm{ddd}(14.0,6.5,3.0)$ & $37.5, \mathrm{CH}_{2}$ & $\mathrm{H}_{2}-10$ & $\mathrm{C}-9,-10,-12,-20$ \\
& $1.42 \mathrm{ddd}(14.0,11.0,3.0)$ & & & \\
12 & & $60.3, \mathrm{C}$ & & \\
13 & $2.87 \mathrm{dd}(7.5,5.5)$ & $61.2, \mathrm{CH}^{2}$ & $\mathrm{H}_{2}-14$ & $\mathrm{C}-11,-12,-14$ \\
14 & $1.85 \mathrm{ddd}(14.0,10.0,5.5) ; 1.61 \mathrm{~m}$ & $34.1, \mathrm{CH}_{2}$ & $\mathrm{H}-1, \mathrm{H}-13$ & $\mathrm{C}-1,-2,-12,-13,-15$ \\
15 & & $142.7, \mathrm{C}$ & & \\
16 & & $170.8, \mathrm{C}$ & & \\
17 & $6.40 \mathrm{~s} ; 5.68 \mathrm{~s}$ & $126.5, \mathrm{CH}_{2}$ & & $\mathrm{C}-1,-15,-16$ \\
18 & $1.26 \mathrm{~s}$ & $24.7, \mathrm{CH}_{3}$ & & $\mathrm{C}-3,-4,-5$ \\
19 & $1.67 \mathrm{~s}$ & $18.1, \mathrm{CH}_{3}$ & $\mathrm{H}-9$ & $\mathrm{C}-7,-8,-9$ \\
20 & $1.30 \mathrm{~s}$ & $17.1, \mathrm{CH}_{3}$ & & $\mathrm{C}-11,-12,-13$ \\
\hline
\end{tabular}


Figure 2. ${ }^{1} \mathrm{H}-{ }^{1} \mathrm{H}$ COSY and selected $\mathrm{HMBC}$ correlations (protons $\rightarrow$ quaternary carbons) for cembrane 1 .

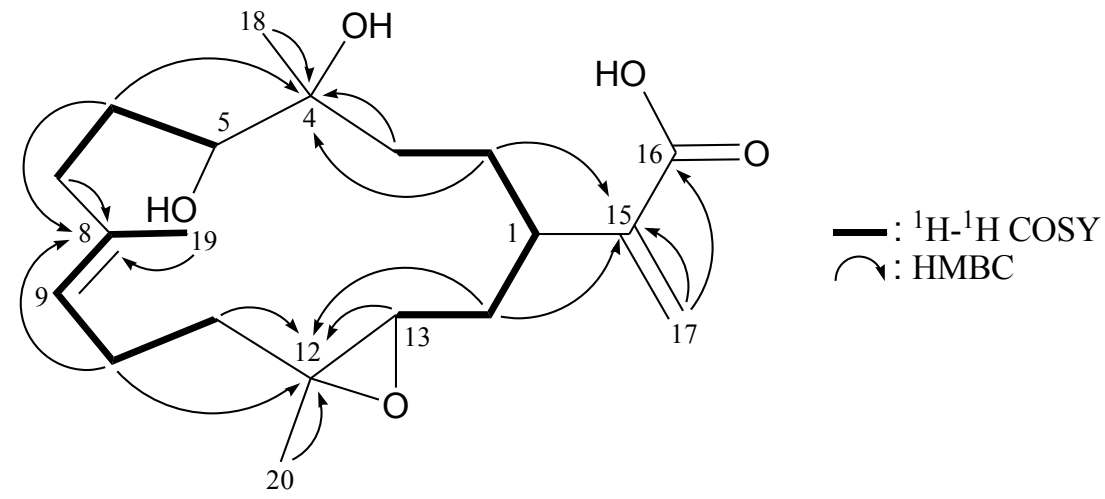

The relative configuration of $\mathbf{1}$ was elucidated from the interactions observed in a NOESY experiment, as shown in Figure 3. In the NOESY experiment of 1, H-1 was found to be correlated with $\mathrm{H}_{2}-14$, but not with $\mathrm{H}-13$; this, plus, the lack of correlation between $\mathrm{H}-13$ and $\mathrm{H}_{3}-20$ demonstrated that $\mathrm{H}-1, \mathrm{H}-13$ and Me-20 were $\alpha$-, $\beta$ - and $\alpha$-oriented, respectively. Additionally, correlations between $\mathrm{H}-9 / \mathrm{H}-5$ and $\mathrm{H}-9 / \mathrm{H}-13$, and the absence of correlation between $\mathrm{H}-9 / \mathrm{H}_{3}-19$, reflected the $E$ geometry of the double bond at C-8/9. From modeling analysis, H-9 was found to be close to H-5 and H-13, when $\mathrm{H}-5$ and $\mathrm{H}-13$ were $\beta$-oriented. $\mathrm{H}_{3}-18$ was found to be correlated with $\mathrm{H}-5$, but not with $\mathrm{H}-1$, indicating that the 4-hydroxy group was $\alpha$-oriented. Based on the above findings, the structure of 1 was elucidated, and the chiral carbons of 1 were assigned as $1 R^{*}, 4 R^{*}, 5 S^{*}, 12 S^{*}$ and $13 S^{*}$.

Figure 3. Key NOESY correlations of $\mathbf{1}$.

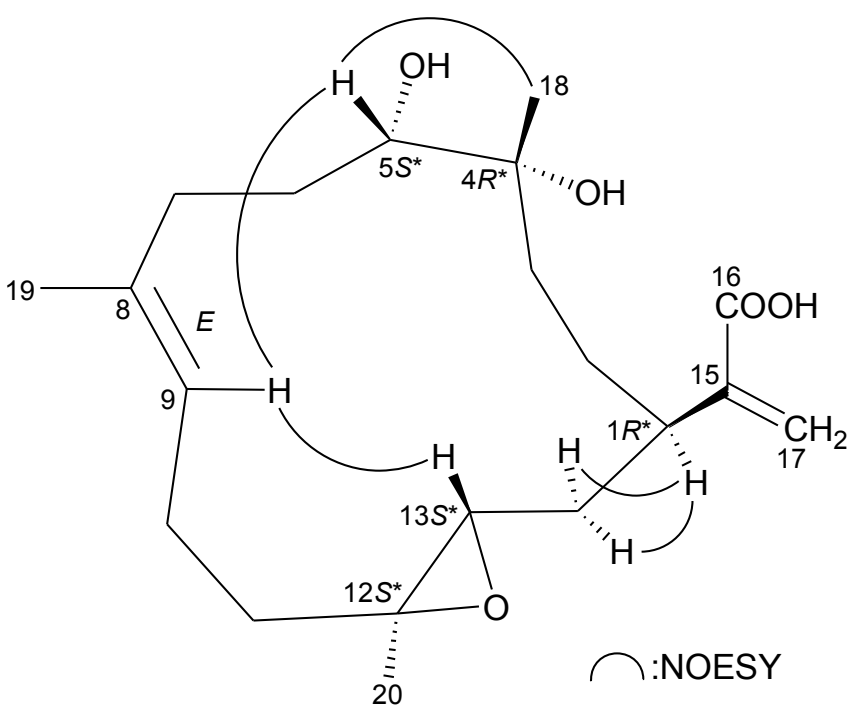

The new cembrane diterpene, flexibilin B (2), had the molecular formula, $\mathrm{C}_{20} \mathrm{H}_{30} \mathrm{O}_{5}$, as deduced by HRESIMS ( $\mathrm{m} / \mathrm{z}$ calcd.: 373.1991 ; found $\left.373.1989[\mathrm{M}+\mathrm{Na}]^{+}\right)\left(6^{\circ}\right.$ of unsaturation). The IR spectrum of 2 revealed the presence of carboxylic acid $\left(v_{\max } 3700-2400 \mathrm{~cm}^{-1}\right)$, hydroxy $\left(v_{\max } 3447 \mathrm{~cm}^{-1}\right)$ and carbonyl $\left(v_{\max } 1713 \mathrm{~cm}^{-1}\right)$ moieties. From the ${ }^{13} \mathrm{C}$ NMR and DEPT spectra of 2 (Table 2), a trisubstituted olefin $\left(\delta_{\mathrm{C}} 134.5, \mathrm{C}-8 ; 126.5, \mathrm{CH}-9\right)$, a $\alpha$-exomethylene-carboxylic acid $\left(\delta_{\mathrm{C}} 171.3, \mathrm{C}-16\right.$; $\left.141.9, \mathrm{C}-15 ; 126.2, \mathrm{CH}_{2}-17\right)$, a keto carbonyl $\left(\delta_{\mathrm{C}} 213.6, \mathrm{C}-5\right)$ and a trisubstituted epoxide $\left(\delta_{\mathrm{C}} 60.8\right.$, 
$\mathrm{C}-12 ; 59.4, \mathrm{CH}-13$ ) were observed. The coupling information in the ${ }^{1} \mathrm{H}-{ }^{1} \mathrm{H}$ COSY spectrum of 2 enabled identification of the $\mathrm{H}-13 / \mathrm{H}_{2}-14 / \mathrm{H}-1 / \mathrm{H}_{2}-2 / \mathrm{H}_{2}-3, \mathrm{H}_{2}-6 / \mathrm{H}_{2}-7, \mathrm{H}-9 / \mathrm{H}_{2}-10 / \mathrm{H}_{2}-11$ and $\mathrm{H}-9 / \mathrm{H}_{3}-19$ (by allylic coupling) units. From these data, together with the results of an HMBC experiment for 2 (Table 2 and Figure 4), the molecular framework of 2 could be established.

Table 2. ${ }^{1} \mathrm{H}\left(500 \mathrm{MHz}, \mathrm{CDCl}_{3}\right)$ and ${ }^{13} \mathrm{C}\left(125 \mathrm{MHz}, \mathrm{CDCl}_{3}\right) \mathrm{NMR}$ data and ${ }^{1} \mathrm{H}-{ }^{1} \mathrm{H} \mathrm{COSY}$ and HMBC correlations for cembrane 2.

\begin{tabular}{clccl}
\hline Position & $\boldsymbol{\delta}_{\mathbf{H}}(\boldsymbol{J}$ in Hz) & $\boldsymbol{\delta}_{\mathbf{C}}$, Multiple & ${ }^{\mathbf{1}} \mathbf{H}^{-1} \mathbf{H}_{\mathbf{C O S Y}}$ & $\mathbf{H M B C}$ \\
\hline 1 & $2.75 \mathrm{~m}$ & $35.9, \mathrm{CH}$ & $\mathrm{H}_{2}-2, \mathrm{H}_{2}-14$ & $\mathrm{C}-14$ \\
2 & $1.59 \mathrm{~m} ; 1.41 \mathrm{~m}$ & $25.1, \mathrm{CH}_{2}$ & $\mathrm{H}-1, \mathrm{H}_{2}-3$ & $\mathrm{C}-4,-15$ \\
3 & $1.78 \mathrm{~m} ; 1.52 \mathrm{~m}$ & $35.8, \mathrm{CH}_{2}$ & $\mathrm{H}_{2}-2$ & $\mathrm{C}-4,-5,-18$ \\
4 & & $78.9, \mathrm{C}$ & & \\
5 & & $213.6, \mathrm{C}$ & & \\
6 & $2.70 \mathrm{~m}$ & $34.2, \mathrm{CH}_{2}$ & $\mathrm{H}_{2}-7$ & $\mathrm{C}-5,-7,-8$ \\
7 & $2.55 \mathrm{~m} ; 2.21 \mathrm{~m}$ & $31.5, \mathrm{CH}_{2}$ & $\mathrm{H}_{2}-6$ & $\mathrm{C}-5,-6,-8,-9,-19$ \\
8 & & $134.5, \mathrm{C}$ & & \\
9 & $5.13 \mathrm{dd}(6.0,6.0)$ & $126.5, \mathrm{CH}^{-}$ & $\mathrm{H}_{2}-10, \mathrm{H}_{3}-19$ & $\mathrm{C}-7,-10,-11,-19$ \\
10 & $2.10 \mathrm{~m} ; 2.01 \mathrm{~m}$ & $22.8, \mathrm{CH}_{2}$ & $\mathrm{H}-9, \mathrm{H}_{2}-11$ & $\mathrm{C}-8,-9,-11,-12$ \\
11 & $1.96 \mathrm{~m} ; 1.56 \mathrm{~m}$ & $36.7, \mathrm{CH}_{2}$ & $\mathrm{H}_{2}-10$ & $\mathrm{C}-9,-10,-12,-13$ \\
12 & & $60.8, \mathrm{C}$ & & \\
13 & $2.79 \mathrm{dd}(9.5,4.0)$ & $59.4, \mathrm{CH}^{2}$ & $\mathrm{H}_{2}-14$ & $\mathrm{C}-14$ \\
14 & $1.99 \mathrm{~m} ; 1.42 \mathrm{~m}$ & $32.4, \mathrm{CH}_{2}$ & $\mathrm{H}-1, \mathrm{H}-13$ & $\mathrm{C}-1,-12,-13,-15$ \\
15 & & $141.9, \mathrm{C}$ & & \\
16 & & $171.3, \mathrm{C}$ & & \\
17 & $6.42, \mathrm{~s} ; 5.57 \mathrm{~s}$ & $126.2, \mathrm{CH}_{2}$ & & $\mathrm{C}-1,-15,-16$ \\
18 & $1.35 \mathrm{~s}$ & $25.7, \mathrm{CH}_{3}$ & & $\mathrm{C}-3,-4,-5$ \\
19 & $1.66 \mathrm{~s}$ & $17.0, \mathrm{CH}_{3}$ & $\mathrm{H}-9$ & $\mathrm{C}-7,-8,-9$ \\
20 & $1.27 \mathrm{~s}$ & $18.2, \mathrm{CH}_{3}$ & & $\mathrm{C}-11,-12,-13$ \\
\hline
\end{tabular}

Figure 4. ${ }^{1} \mathrm{H}-{ }^{1} \mathrm{H}$ COSY and selected HMBC correlations (protons $\rightarrow$ quaternary carbons) for cembrane 2.

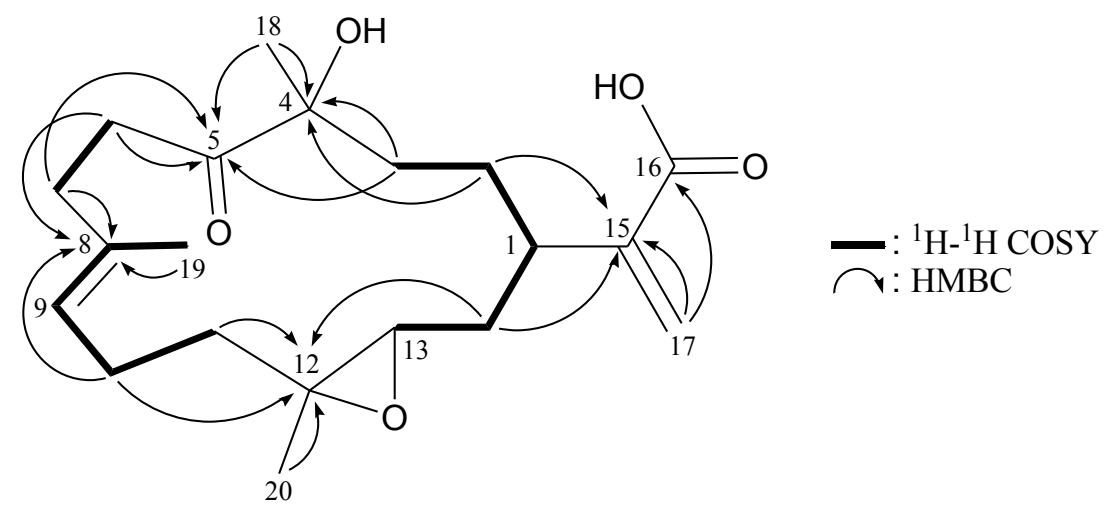

The relative stereochemistry of $\mathbf{2}$ was elucidated from the interactions observed in a NOESY experiment (Figure 5). Due to the $\alpha$-orientation of $\mathrm{H}-1$, the epoxy proton, $\mathrm{H}-13$, was identified as being $\beta$-oriented, as no correlation was observed between H-1 and H-13. H-9 displayed correlations with 
H-13 and one of the C-7 methylene protons $\left(\delta_{\mathrm{H}} 2.55\right)$, and there was a lack of correlation between $\mathrm{H}-9$ and $\mathrm{H}_{3}-19$, which reflects the $E$ geometry of the double bond between $\mathrm{C}-8 / 9 . \mathrm{H}_{3}-20$ showed correlations with $\mathrm{H}-9$ and $\mathrm{H}-13$, indicating that $\mathrm{Me}-20$ is of a $\beta$-orientation at $\mathrm{C}-12$. Furthermore, $\mathrm{H}-1$ was found to be correlated with $\mathrm{H}_{2}-3$, and $\mathrm{H}_{3}-18$ exhibited a correlation with one of the $\mathrm{C}-3$ methylene protons $\left(\delta_{\mathrm{H}} 1.78\right)$, which indicated the $\beta$-orientation of Me-18 at C-4 by molecular modeling analysis. Based on the above information, the chiral carbons of cembrane 2 were assigned as $1 R^{*}, 4 R^{*}, 12 R^{*}$ and $13 S^{*}$.

Figure 5. Key NOESY correlations of 2.

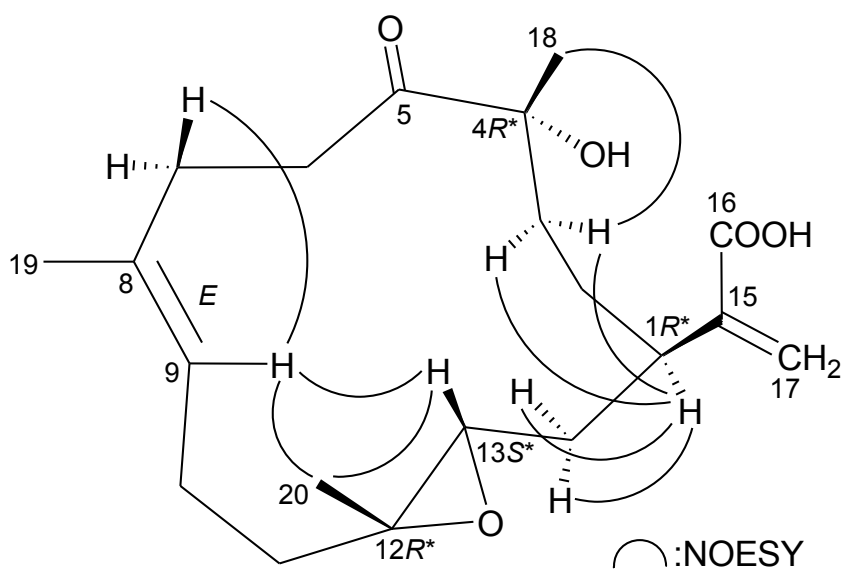

Flexibilin C (3) was obtained as a white powder. The molecular formula of $\mathbf{3}$ was established as $\mathrm{C}_{20} \mathrm{H}_{30} \mathrm{O}_{5}$ (6 $6^{\circ}$ of unsaturation) from a sodiated molecule at $\mathrm{m} / z 373$ in the ESIMS spectrum and further supported by HRESIMS ( $m / z$ 373.1989, calcd. for $\left.\mathrm{C}_{20} \mathrm{H}_{30} \mathrm{O}_{5} \mathrm{Na}, 373.1991\right)$. The IR spectrum of 3 exhibited the presence of hydroxy $\left(v_{\max } 3431 \mathrm{~cm}^{-1}\right)$ and carbonyl $\left(v_{\max } 1711 \mathrm{~cm}^{-1}\right)$ groups. From the ${ }^{13} \mathrm{C}$ NMR data of 3 (Table 3), a suite of resonances at $\delta_{\mathrm{C}} 168.0$ (C-16), $143.3(\mathrm{C}-15), 126.0\left(\mathrm{CH}_{2}-17\right), 90.0$ $(\mathrm{C}-4), 37.4(\mathrm{CH}-1), 33.7\left(\mathrm{CH}_{2}-3\right)$ and $29.7\left(\mathrm{CH}_{2}-2\right)$ could be assigned to the $\alpha$-exomethylene- $\varepsilon$-lactone moiety. Two additional unsaturated functionalities were indicated by ${ }^{13} \mathrm{C}$ resonances at $\delta_{\mathrm{C}} 209.3(\mathrm{C}-5)$, 134.7 (C-8) and 124.9 (CH-9), suggesting the presence of a keto carbonyl and a trisubstituted olefin. On the basis of the overall unsaturation data, $\mathbf{3}$ was concluded to be a diterpenoid molecule possessing two rings. The ${ }^{1} \mathrm{H}$ NMR spectrum of $\mathbf{3}$ showed the presence of three methyl groups: two singlets at $\delta_{\mathrm{H}}$ 1.27 and 1.49 , representing the methyl groups on oxygenated quaternary carbons, respectively, and a vinyl methyl at $\delta_{\mathrm{H}} 1.69$. The ${ }^{1} \mathrm{H}$ NMR coupling information in the ${ }^{1} \mathrm{H}-{ }^{1} \mathrm{H}$ COSY spectrum of 3 enabled identification of the $\mathrm{H}-13 / \mathrm{H}_{2}-14 / \mathrm{H}-1 / \mathrm{H}_{2}-2 / \mathrm{H}_{2}-3, \mathrm{H}_{2}-6 / \mathrm{H}_{2}-7, \mathrm{H}-9 / \mathrm{H}_{2}-10 / \mathrm{H}_{2}-11$ and $\mathrm{H}-9 / \mathrm{H}_{3}-19$ (by allylic coupling) units, which were assembled with the assistance of an HMBC experiment (Table 3 and Figure 6). The key HMBC correlations between protons and quaternary carbons of $\mathbf{3}$, such as $\mathrm{H}_{2}-2$, $\mathrm{H}_{2}-3, \mathrm{H}_{3}-18 / \mathrm{C}-4 ; \mathrm{H}_{2}-3, \mathrm{H}_{2}-6, \mathrm{H}_{2}-7, \mathrm{H}_{3}-18 / \mathrm{C}-5 ; \mathrm{H}_{2}-6, \mathrm{H}_{2}-7, \mathrm{H}_{2}-10, \mathrm{H}_{3}-19 / \mathrm{C}-8 ; \mathrm{H}_{2}-10, \mathrm{H}_{2}-11, \mathrm{H}_{2}-14$, $\mathrm{H}_{3}-20 / \mathrm{C}-12 ; \mathrm{H}-1, \mathrm{H}_{2}-2, \mathrm{H}_{2}-14, \mathrm{H}_{2}-17 / \mathrm{C}-15$; and $\mathrm{H}-1, \mathrm{H}_{2}-17, \mathrm{H}_{3}-18 / \mathrm{C}-16$, enabled establishment of the main carbon skeleton of 3. A vinyl methyl at C-8 was confirmed by the allylic coupling between $\mathrm{H}-9 / \mathrm{H}_{3}-19$ in the ${ }^{1} \mathrm{H}-{ }^{1} \mathrm{H}$ COSY spectrum and by the HMBC correlations between $\mathrm{H}_{3}-19 / \mathrm{C}-7,-8,-9$. The tertiary methyls at C- 4 and C-12 were confirmed by the HMBC correlations between $\mathrm{H}_{3}-18 / \mathrm{C}-3,-4$, -5 , and $\mathrm{H}_{3}-20 / \mathrm{C}-11,-12,-13 . \mathrm{H}_{3}-18$ showed a long-range ${ }^{4} J$-correlation with the ester carbonyl $\left(\delta_{\mathrm{C}} 168.0\right.$, $\mathrm{C}-16)$ in the HMBC spectrum, which further supported the existence of the $\varepsilon$-lactone moiety in 3. 
Table 3. ${ }^{1} \mathrm{H}\left(500 \mathrm{MHz}, \mathrm{CDCl}_{3}\right)$ and ${ }^{13} \mathrm{C}\left(125 \mathrm{MHz}, \mathrm{CDCl}_{3}\right) \mathrm{NMR}$ data and ${ }^{1} \mathrm{H}-{ }^{1} \mathrm{H} \mathrm{COSY}$ and $\mathrm{HMBC}$ correlations for cembrane $\mathbf{3}$.

\begin{tabular}{|c|c|c|c|c|}
\hline Position & $\delta_{\mathrm{H}}(J$ in $\mathrm{Hz})$ & $\delta_{\mathrm{C}}$, Multiple & ${ }^{1} \mathrm{H}-{ }^{1} \mathrm{H}$ COSY & НMBC \\
\hline 1 & $1.90 \mathrm{~m}$ & $37.4, \mathrm{CH}$ & $\mathrm{H}_{2}-2, \mathrm{H}_{2}-14$ & $C-2,-14,-15,-16,-17$ \\
\hline 2 & $2.19 \mathrm{~m} ; 1.20 \mathrm{ddd}(12.5,12.5,7.0)$ & 29.7, $\mathrm{CH}_{2}$ & $\mathrm{H}-1, \mathrm{H}_{2}-3$ & $C-1,-2,-3,-4,-14,-15$ \\
\hline 3 & $2.45 \mathrm{dd}(15.5,7.0) ; 1.91 \mathrm{~m}$ & $33.7, \mathrm{CH}_{2}$ & $\mathrm{H}_{2}-2$ & $C-1,-2,-4,-5,-18$ \\
\hline 4 & & $90.0, \mathrm{C}$ & & \\
\hline 5 & & 209.3, C & & \\
\hline 6 & $3.36 \mathrm{dd}(17.0,9.5) ; 2.56$ br d (17.0) & $33.6, \mathrm{CH}_{2}$ & $\mathrm{H}_{2}-7$ & $C-5,-7,-8$ \\
\hline 7 & 2.57 br d (16.0); $2.15 \mathrm{~m}$ & $31.0, \mathrm{CH}_{2}$ & $\mathrm{H}_{2}-6$ & $C-5,-6,-8,-9,-19$ \\
\hline 8 & & 134.7, C & & \\
\hline 9 & $4.99 \mathrm{dd}(6.5,6.5)$ & $124.9, \mathrm{CH}$ & $\mathrm{H}_{2}-10, \mathrm{H}_{3}-19$ & $C-7,-9,-10,-19$ \\
\hline 10 & $2.14 \mathrm{~m}$ & $23.5, \mathrm{CH}_{2}$ & $\mathrm{H}-9, \mathrm{H}_{2}-11$ & $C-8,-9,-11,-12$ \\
\hline 11 & $1.66 \mathrm{~m}$ & $38.2, \mathrm{CH}_{2}$ & $\mathrm{H}_{2}-10$ & $C-9,-10,-12,-13,-20$ \\
\hline 12 & & 76.2, C & & \\
\hline 13 & $3.26 \mathrm{dd}(6.0,1.5)$ & $75.5, \mathrm{CH}$ & $\mathrm{H}_{2}-14$ & $\mathrm{C}-1,-11,-14,-20$ \\
\hline 14 & $\begin{array}{l}2.03 \mathrm{dd}(14.5,1.5) \\
1.40 \mathrm{ddd}(14.5,11.0,6.0)\end{array}$ & $35.3, \mathrm{CH}_{2}$ & $\mathrm{H}-1, \mathrm{H}-13$ & $C-1,-2,-12,-13,-15$ \\
\hline 15 & & 143.3, C & & \\
\hline 16 & & $168.0, \mathrm{C}$ & & \\
\hline 17 & $6.35 \mathrm{~s} ; 5.58 \mathrm{~s}$ & 126.0, $\mathrm{CH}_{2}$ & & $C-1,-15,-16$ \\
\hline 18 & $1.49 \mathrm{~s}$ & $29.6, \mathrm{CH}_{3}$ & & $C-3,-4,-5,-16$ \\
\hline 19 & $1.69 \mathrm{~s}$ & $17.4, \mathrm{CH}_{3}$ & H-9 & $C-7,-8,-9$ \\
\hline 20 & $1.27 \mathrm{~s}$ & $24.6, \mathrm{CH}_{3}$ & & $C-11,-12,-13$ \\
\hline
\end{tabular}

Figure 6. ${ }^{1} \mathrm{H}-{ }^{1} \mathrm{H}$ COSY and selected $\mathrm{HMBC}$ correlations (protons $\rightarrow$ quaternary carbons) for cembrane 3.

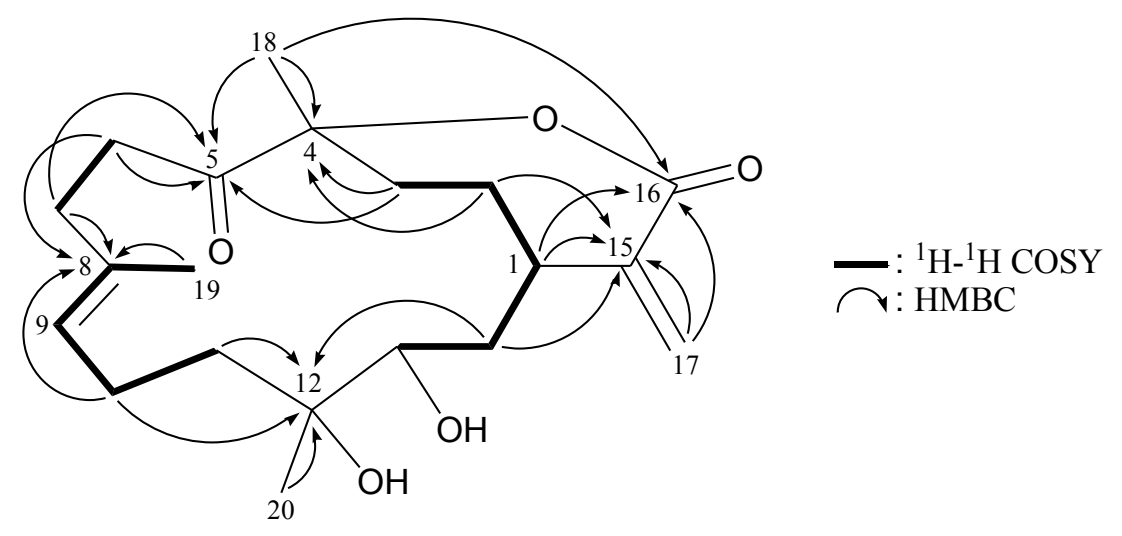

The relative stereochemistry of $\mathbf{3}$ was elucidated by the analysis of NOE correlations, as shown in Figure 7. H-9 exhibited a correlation with one of the C-6 methylene protons $\left(\delta_{\mathrm{H}} 3.36\right)$, but not with $\mathrm{H}_{3}-19$, which revealed the $E$ geometry of the C-8/9 double bond. It was found that $\mathrm{H}-13$ showed correlations with H-1 and H-9. From molecular modeling analysis, H-13 was found to be close to H-1 and $\mathrm{H}-9$, when $\mathrm{H}-1$ and $\mathrm{H}-13$ were $\alpha$-oriented. Correlations observed between $\mathrm{H}_{3}-20 / \mathrm{H}-13$ and $\mathrm{H}_{3}-20 / \mathrm{H}_{2}-10$ reflected the $\beta$-orientation of Me-20. Furthermore, $\mathrm{H}_{3}-18$ exhibited correlations with C-3 methylene protons and the lack of correlation between $\mathrm{H}_{3}-18$ and $\mathrm{H}-1$, indicating that Me-18 was 
positioned on the $\beta$-face in $\mathbf{3}$. Thus, the structure of $\mathbf{3}$ was established, and the chiral carbons of $\mathbf{3}$ were assigned as $1 R^{*}, 4 R^{*}, 12 R^{*}$ and $13 S^{*}$.

Figure 7. Key NOESY correlations of $\mathbf{3}$.

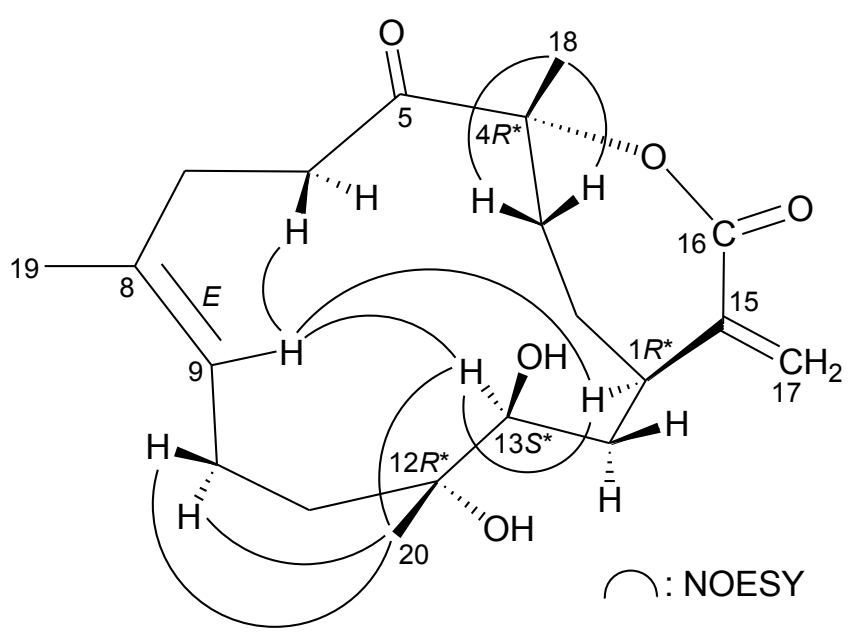

The known cembrane, (-)-sandensolide (4), was first isolated from a Chinese soft coral, Dendronephthya sp. [23], and its structure was elucidated by spectroscopic methods and by comparison of spectral (1D and 2D NMR) and physical (rotation value) data with those of its enantiomer, sandensolide [10,22]. In this study, the structure of $\mathbf{4}$, including its absolute stereochemistry, was further established by single-crystal X-ray diffraction analysis for the first time. The X-ray structure of 4 (Figure 8) demonstrates the $E$ geometry of the C-8/9 and C-11/12 double bonds, and the absolute configurations for all chiral carbons were assigned as $1 R, 4 R, 5 S$ and $13 S$. As flexibilins A-C (1-3) were isolated, along with (-)-sandensolide (4), from the same organism, it is reasonable on biogenetic grounds to assume that cembranes 1-3 have the same absolute configurations as 4 .

Figure 8. Molecular plot of $\mathbf{4}$ with confirmed absolute configuration.

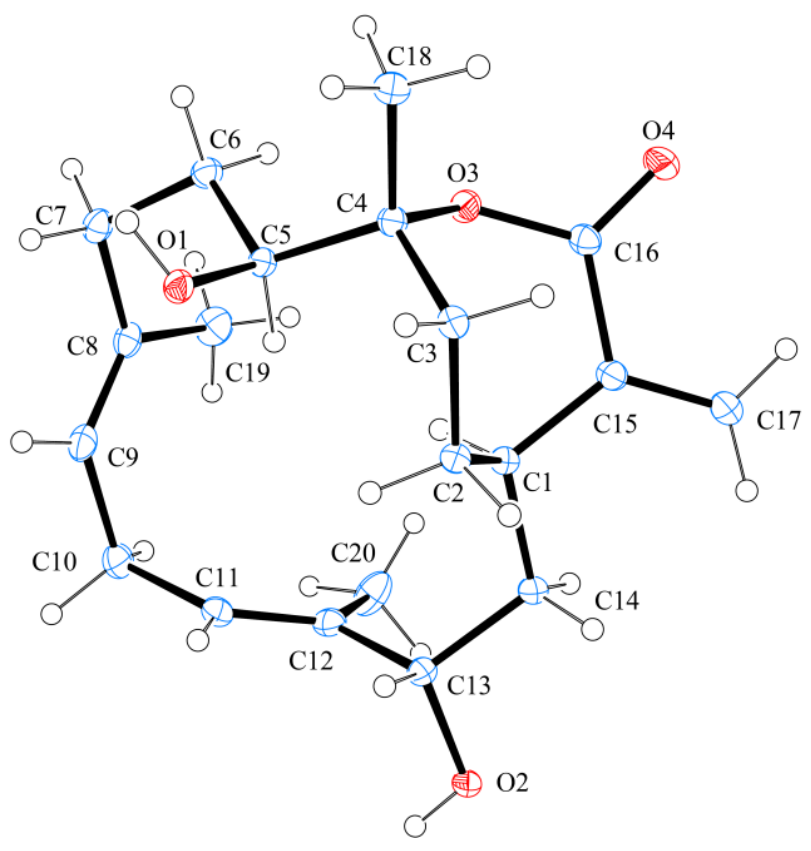


The in vitro anti-inflammatory effects of cembranes 1-4 were examined, and cembrane $\mathbf{2}$ displayed a moderate inhibitory effect on the release of elastase by human neutrophils (Table 4) [24].

Table 4. Inhibitory effects of cembranes 1-4 on the generation of superoxide anions and the release of elastase by human neutrophils in response to fMLP/CB.

\begin{tabular}{ccc|cc}
\hline \multirow{2}{*}{ Compound } & \multicolumn{2}{c|}{ Superoxide anions } & \multicolumn{2}{c}{ Elastase release } \\
\cline { 2 - 5 } & $\mathbf{I C}_{\mathbf{5 0}}(\boldsymbol{\mu} \mathbf{g} / \mathbf{m L})$ & $\mathbf{I n h}^{\mathbf{a}}$ & $\mathbf{I C}_{\mathbf{5 0}}(\boldsymbol{\mu} \mathbf{g} / \mathbf{m L})$ & $\mathbf{I n h}^{\mathbf{a}}$ \\
\hline $\mathbf{1}$ & $>10$ & $12.31 \pm 3.04^{*}$ & $>10$ & $22.67 \pm 5.32 *$ \\
$\mathbf{2}$ & $>10$ & $22.03 \pm 3.88^{* *}$ & $>10$ & $45.76 \pm 2.92 * * *$ \\
$\mathbf{3}$ & $>10$ & $18.80 \pm 3.81^{* *}$ & $>10$ & $10.56 \pm 2.75 *$ \\
$\mathbf{4}$ & $>10$ & $-2.08 \pm 1.01$ & $>10$ & $8.14 \pm 4.03$ \\
$\mathbf{L Y 2 9 4 0 0 2}^{\mathbf{b}}$ & $0.41 \pm 0.27$ & & $0.79 \pm 0.18$ & \\
\hline
\end{tabular}

${ }^{\mathrm{a}}$ Percentage of inhibition (Inh\%) at a concentration of $10 \mu \mathrm{g} / \mathrm{mL}$. ${ }^{\mathrm{b}} \mathrm{LY} 294002$, a phosphatidylinositol-3-kinase inhibitor, was used as a positive control for inhibition of superoxide anion generation and elastase release. The results are presented as the mean \pm S.E.M. $(n=3$ or 4$) .{ }^{*} p<0.05,{ }^{* *} p<0.01,{ }^{* * *} p<0.001$, compared with the control value.

\section{Experimental Section}

\subsection{General Experimental Procedures}

Optical rotations were measured on a Jasco P-1010 digital polarimeter. Infrared spectra were recorded on a Varian Diglab FTS 1000 FT-IR spectrometer; peaks are reported in $\mathrm{cm}^{-1}$. The NMR spectra were recorded on a Varian Inova 500 or on a Varian Mercury Plus 400 NMR spectrometer using the residual $\mathrm{CHCl}_{3}$ signal $\left(\delta_{\mathrm{H}} 7.26 \mathrm{ppm}\right)$ as the internal standard for ${ }^{1} \mathrm{H} \mathrm{NMR}$ and $\mathrm{CDCl}_{3}$ $\left(\delta_{\mathrm{C}} 77.1 \mathrm{ppm}\right)$ for ${ }^{13} \mathrm{C}$ NMR. Coupling constants $(J)$ are given in Hz. ESIMS and HRESIMS were recorded on a Bruker APEX II mass spectrometer. Column chromatography was performed on silica gel (230-400 mesh, Merck, Darmstadt, Germany). TLC was carried out on precoated Kieselgel $60 \mathrm{~F}_{254}$ ( $0.25 \mathrm{~mm}$, Merck); spots were visualized by spraying with $10 \% \mathrm{H}_{2} \mathrm{SO}_{4}$ solution, followed by heating. HPLC was performed using a system comprised of a Hitachi L-7110 pump and a Rheodyne injection port. A normal phase semi-preparative column (Supelco Ascentis ${ }^{\circledR}$ Si cat\#:581515-U, $250 \times 21.2 \mathrm{~mm}$, $5 \mu \mathrm{m})$ was used for HPLC.

\subsection{Animal Material}

Specimens of the octocoral S. flexibilis were collected by hand using scuba equipment off the coast of southern Taiwan in July, 2011, and stored in a freezer until extraction. A voucher specimen (NMMBA-TWSC-11005) was deposited in the National Museum of Marine Biology and Aquarium, Taiwan.

\subsection{Extraction and Isolation}

Sliced bodies of the soft coral $S$. flexibilis (wet weight $3.0 \mathrm{~kg}$, dry weight $950 \mathrm{~g}$ ) were extracted with ethyl acetate (EtOAc). The EtOAc layer was separated by silica gel and eluted using $n$-hexane/EtOAc in a stepwise fashion from pure $n$-hexane-100:1-pure EtOAc to yield 11 fractions, A-K. Fraction J 
was chromatographed on silica gel and eluted using $n$-hexane/EtOAc (stepwise, 2:1-1:1) to afford subfractions 1-10. Fractions J3, J5 and J9 were separated by normal-phase HPLC (NP-HPLC) using a mixture of $n$-hexane and acetone as the mobile phase to afford $4(3: 1,74.3 \mathrm{mg}), 3(2: 1,5.6 \mathrm{mg})$ and 2 $(3: 1,16.6 \mathrm{mg})$, respectively. Fraction K was further purified by NP-HPLC using a mixture of $n$-hexane and acetone as the mobile phase to afford $\mathbf{1}(2: 1,22.4 \mathrm{mg})$.

Flexibilin A (1): yellowish oil; $[\alpha]_{\mathrm{D}}^{25}-9$ (c 0.47, $\mathrm{CHCl}_{3}$ ); IR (neat) $v_{\max }$ 3750-2400 (br.), 3419, $1711 \mathrm{~cm}^{-1} ;{ }^{1} \mathrm{H}\left(\mathrm{CDCl}_{3}, 500 \mathrm{MHz}\right)$ and ${ }^{13} \mathrm{C}\left(\mathrm{CDCl}_{3}, 125 \mathrm{MHz}\right)$ NMR data-see Table 1; ESIMS: $\mathrm{m} / z$ $375(\mathrm{M}+\mathrm{Na})^{+}$; HRESIMS: $m / z 375.2144$ (calcd. for $\mathrm{C}_{20} \mathrm{H}_{32} \mathrm{O}_{5} \mathrm{Na}, 375.2147$ ).

Flexibilin B (2): colorless oil; $[\alpha]_{\mathrm{D}}^{25}+29$ (c 0.83, $\mathrm{CHCl}_{3}$ ); IR (neat) $v_{\max }$ 3700-2400 (br.), 3447, $1713 \mathrm{~cm}^{-1} ;{ }^{1} \mathrm{H}\left(\mathrm{CDCl}_{3}, 500 \mathrm{MHz}\right)$ and ${ }^{13} \mathrm{C}\left(\mathrm{CDCl}_{3}, 125 \mathrm{MHz}\right)$ NMR data-see Table 2; ESIMS: $\mathrm{m} / z$ $373(\mathrm{M}+\mathrm{Na})^{+}$; HRESIMS: $m / z 373.1989$ (calcd. for $\mathrm{C}_{20} \mathrm{H}_{30} \mathrm{O}_{5} \mathrm{Na}, 373.1991$ ).

Flexibilin C (3): white powder; $\mathrm{mp} 95-97{ }^{\circ} \mathrm{C}$; $[\alpha]_{\mathrm{D}}^{25}+4\left(c 0.28, \mathrm{CHCl}_{3}\right)$; IR (neat) $v_{\max } 3431,1711 \mathrm{~cm}^{-1}$; ${ }^{1} \mathrm{H}\left(\mathrm{CDCl}_{3}, 500 \mathrm{MHz}\right)$ and ${ }^{13} \mathrm{C}\left(\mathrm{CDCl}_{3}, 125 \mathrm{MHz}\right) \mathrm{NMR}$ data-see Table 3; ESIMS: $\mathrm{m} / z 373$ $(\mathrm{M}+\mathrm{Na})^{+}$; HRESIMS: $m / z 373.1989$ (calcd. for $\left.\mathrm{C}_{20} \mathrm{H}_{30} \mathrm{O}_{5} \mathrm{Na}, 373.1991\right)$.

(-)-Sandensolide (4): white powder; mp 178-180 ${ }^{\circ} \mathrm{C}$; $[\alpha]_{\mathrm{D}}^{25}-43\left(c\right.$ 0.67, $\left.\mathrm{CHCl}_{3}\right)$ (reference [23], $\left.[\alpha]_{\mathrm{D}}^{20}-45.0\left(c 0.5, \mathrm{CHCl}_{3}\right)\right)$; IR (neat) $v_{\max } 3431,1691 \mathrm{~cm}^{-1} ;{ }^{1} \mathrm{H} \mathrm{NMR}\left(\mathrm{CDCl}_{3}, 400 \mathrm{MHz}\right) \delta_{\mathrm{H}} 6.24(1 \mathrm{H}$, s, H-17), 5.49 (1H, s, H-17'), 5.39 (1H, m, H-11), 5.36 (1H, m, H-9), 4.18 (1H, dd, J = 11.2, 4.4 Hz, H-13), $3.77(1 \mathrm{H}, \mathrm{d}, J=10.4 \mathrm{~Hz}, \mathrm{H}-5), 3.13(1 \mathrm{H}, \mathrm{ddd}, J=13.2,11.6,10.4 \mathrm{~Hz}, \mathrm{H}-10), 2.40$ (1H, m, H-10'), 2.21 (1H, m, H-7), 2.13 (1H, m, H-3), 2.05 (1H, m, H-7'), 2.04 (1H, m, H-2), 2.01 (1H, m, H-1), 1.99 (1H, m, H-6), 1.80 (1H, m, H-14), $1.72\left(1 \mathrm{H}, \mathrm{m}, \mathrm{H}-14^{\prime}\right), 1.70\left(1 \mathrm{H}, \mathrm{m}, \mathrm{H}-3^{\prime}\right), 1.62(3 \mathrm{H}, \mathrm{s}$, $\left.\mathrm{H}_{3}-18\right), 1.52$ (3H, s, H $\left.{ }_{3}-19\right), 1.35$ (1H, dddd, $J=14.0,10.4,3.6,3.6 \mathrm{~Hz}, \mathrm{H}-6$ ') $1.26\left(3 \mathrm{H}, \mathrm{s}, \mathrm{H}_{3}-20\right)$, $1.14\left(1 \mathrm{H}, \mathrm{m}, \mathrm{H}-2^{\prime}\right) ;{ }^{13} \mathrm{C} \mathrm{NMR}\left(\mathrm{CDCl}_{3}, 100 \mathrm{MHz}\right) \delta_{\mathrm{C}} 169.6(\mathrm{C}-16), 144.6(\mathrm{C}-15), 134.2(\mathrm{C}-8), 132.7$ (C-12), 127.9 (CH-11), 124.7 (CH-9), $124.4\left(\mathrm{CH}_{2}-17\right), 86.6$ (C-4), 76.6 (CH-13), 67.4 (CH-5), 38.0 $\left(\mathrm{CH}_{2}-14\right), 34.8\left(\mathrm{CH}_{2}-7\right), 33.7(\mathrm{CH}-1), 32.0\left(\mathrm{CH}_{2}-3\right), 29.2\left(\mathrm{CH}_{2}-2\right), 26.8\left(\mathrm{CH}_{2}-10\right), 26.6\left(\mathrm{CH}_{2}-6\right), 22.8$ $\left(\mathrm{CH}_{3}-18\right), 14.9\left(\mathrm{CH}_{3}-19\right), 9.3\left(\mathrm{CH}_{3}-20\right)$; ESIMS: $m / z 357(\mathrm{M}+\mathrm{Na})^{+}$; HRESIMS: $m / z$ 357.2040 (calcd. for $\mathrm{C}_{20} \mathrm{H}_{30} \mathrm{O}_{4} \mathrm{Na}, 357.2042$ ).

\subsection{Single-Crystal X-ray Crystallography of (-)-Sandensolide (4) [25]}

Suitable colorless prisms of $\mathbf{4}$ were obtained from a solution of ethyl acetate. Crystal data and experimental details: $\mathrm{C}_{20} \mathrm{H}_{30} \mathrm{O}_{4}, M_{r}=334.44$, crystal size $0.25 \times 0.20 \times 0.20 \mathrm{~mm}$, crystal system monoclinic, space group $P 2_{1}$ (\#4), with $a=9.0281(3) \AA, b=22.2200(8) \AA, c=9.3289(3) \AA$, $\beta=100.547(1)^{\circ}, V=1839.80(11) \AA{ }^{3}, Z=4, D_{\text {calcd }}=1.207 \mathrm{~g} / \mathrm{cm}^{3}$ and $\lambda(\mathrm{Cu}, \mathrm{k} \alpha)=1.54178 \AA$. Intensity data were measured on a Bruker APEX-II CCD diffractometer equipped with a micro-focus $\mathrm{Cu}$ radiation source and Montel mirror up to $\theta_{\max }$ of $26^{\circ}$ at $100 \mathrm{~K}$. All 5454 reflections were collected. The structure was solved by direct methods and refined by a full-matrix least-squares procedure. The refined structural model converged to a final $R 1=0.0294, w R 2=0.0759$ for 5398 observed reflection $[I>2 \sigma(I)]$ and 455 variable parameters. The absolute configuration was determined by Flack's method, with the Flack's parameter determined as 0.06(10) [26]. 


\subsection{Generation of Superoxide Anions and Release of Elastase by Human Neutrophils}

Human neutrophils were obtained by means of dextran sedimentation and Ficoll centrifugation. Measurements of superoxide anion generation and elastase release were carried out according to previously described procedures [27-33]. Briefly, superoxide anion production was assayed by monitoring the superoxide dismutase-inhibitable reduction of ferricytochrome $c$. Elastase release experiments were performed using $\mathrm{MeO}$-Suc-Ala-Ala-Pro-Valp-nitroanilide as the elastase substrate.

\section{Conclusions}

Cembrane-type diterpenoids are the major component of the organic extract of the soft coral, Sinularia flexibilis, collected from the waters of Taiwan, and compounds of this type have been shown to have the potential for use in medical applications. Our studies of S. flexibilis have led to the isolation of three new cembranes, flexibilins A-C (1-3), along with a known metabolite, (-)-sandensolide (4), and flexibilin B (2) displayed a moderate inhibitory effect on the release of elastase by human neutrophils. In addition to marine organisms, cembrane-type diterpenoids are also found in higher plants and bryophytes [34-43]. However, the carboxylic acid moieties exhibited in cembranes 1 and 2 are rarely found $[35,44]$. The soft coral, $S$. flexibilis, has begun to be transplanted to culturing tanks with a flow-through seawater system located in the National Museum of Marine Biology and Aquarium, Taiwan, for exhibition and the extraction of additional natural products in order to establish a stable supply of bioactive material.

\section{Acknowledgments}

This research was supported by grants from the National Museum of Marine Biology and Aquarium; the National Dong Hwa University; the Division of Marine Biotechnology, Asia-Pacific Ocean Research Center, National Sun Yat-sen University (Grant No. 00C-0302-05); the Department of Health Clinical Trial and Research Center of Excellence (Grant No. DOH101-TD-C-111-004); and the National Science Council (Grant No. NSC 102-2325-B-291-001, 101-2325-B-291-001, 100-2325-B-291-001 and 101-2320-B-291-001-MY3), Taiwan; awarded to Y.-H.K. and P.-J.S.

\section{Conflict of Interest}

The authors declare no conflict of interest.

\section{References and Notes}

1. Rocha, J.; Peixe, L.; Gomes, N.C.M.; Calado, R. Cnidarians as a new marine bioactive compounds-An overview of the last decade and future steps for bioprospecting. Mar. Drugs 2011, 9, 1860-1886.

2. Chen, W.-T.; Li, Y.; Guo, Y.-W. Terpenoids of Sinularia soft corals: Chemistry and bioactivity. Acta Pharm. Sin. B 2012, 2, 227-237.

3. Tursch, B.; Braekman, J.C.; Daloze, D.; Herin, M.; Karlsson, R.; Losman, D. Chemcial studies of marine invertebrates-XI. Tetrahedron 1975, 31, 129-133. 
4. Weinheimer, A.J.; Matson, J.A.; Hossain, M.B.; van der Helm, D. Marine anticancer agents: Sinularin and dihydrosinularin, new cembranolides from the soft coral, Sinularia flexibilis. Tetrahedron Lett. 1977, 18, 2923-2926.

5. Kazlauskas, R.; Murphy, P.T.; Wells, R.J.; Schönholzer, P.; Coll, J.C. Cembranoid constituents from an Australian collection of the soft coral Sinularia flexibilis. Aust. J. Chem. 1978, 31, 1817-1824.

6. Mori, K.; Suzuki, S.; Iguchi, K.; Yamada, Y. 8,11-Epoxy bridged cembranolide diterpene from the soft coral Sinularia flexibilis. Chem. Lett. 1983, 12, 1515-1516.

7. Guerrero, P.P.; Read, R.W.; Batley, M.; Janairo, G.C. The structure of a novel cembranoid diterpene from a Philippine collection of the soft coral Sinularia flexibilis. J. Nat. Prod. 1995, 58, 1185-1191.

8. Anjaneyulu, A.S.R.; Sagar, K.S. Flexibilolide and dihydroflexibilolide, the first trihydroxy-cembranolide lactones from the soft coral Sinularia flexibilis of the Indian Ocean. Nat. Prod. Lett. 1996, 9, 127-135.

9. Michalek, K.; Bowden, B.F. A natural algacide from soft coral Sinularia flexibilis (Coelenterata, Octocorallia, Alcyonacea). J. Chem. Ecol. 1997, 23, 259-273.

10. Anjaneyulu, A.S.R.; Sagar, K.S.; Rao, G.V. New cembranoid lactones from the Indian Ocean soft coral Sinularia flexibilis. J. Nat. Prod. 1997, 60, 9-12.

11. Duh, C.-Y.; Wang, S.-K.; Tseng, H.-K.; Sheu, J.-H.; Chiang, M.Y. Novel cytotoxic cembranoids from the soft coral Sinularia flexibilis. J. Nat. Prod. 1998, 61, 844-847.

12. Duh, C.-Y.; Wang, S.-K.; Tseng, H.-K.; Sheu, J.-H. A novel cytotoxic biscembranoid from the Formosan soft coral Sinularia flexibilis. Tetrahedron Lett. 1998, 39, 7121-7122.

13. Hsieh, P.-W.; Chang, F.-R.; McPhail, A.T.; Lee, K.-H.; Wu, Y.-C. New cembranolide analogues from the Formosan soft coral Sinularia flexibilis and their cytotoxicity. Nat. Prod. Res. 2003, 17, 409-418.

14. Wen, T.; Ding, Y.; Deng, Z.; van Ofwegen, L.; Proksch, P.; Lin, W. Sinulaflexiolides A-K, cembrane-type diterpenoids from the Chinese soft coral Sinularia flexibilis. J. Nat. Prod. 2008, 71, 1133-1140.

15. Lo, K.-L.; Khalil, A.T.; Kuo, Y.-H.; Shen, Y.-C. Sinuladiterpenes A-F, new cembrane diterpenes from Sinularia flexibilis. Chem. Biodivers. 2009, 6, 2227-2235.

16. Su, J.-H.; Lin, Y.-F.; Lu, Y.; Yeh, H.-C.; Wang, W.-H.; Fan, T.-Y.; Sheu, J.-H. Oxygenated cembranoids from the cultured and wild-type soft corals Sinularia flexibilis. Chem. Pharm. Bull. 2009, 57, 1189-1192.

17. Lin, Y.-S.; Chen, C.-H.; Liaw, C.-C.; Chen, Y.-C.; Kuo, Y.-H.; Shen, Y.-C. Cembrane diterpenoids from the Taiwanese soft coral Sinularia flexibilis. Tetrahedron 2009, 65, 9157-9164.

18. Lo, K.-L.; Khalil, A.T.; Chen, M.-H.; Shen, Y.-C. New cembrane diterpenes from Taiwanese soft coral Sinularia flexibilis. Helv. Chim. Acta 2010, 93, 1329-1335.

19. Chen, B.-W.; Chao, C.-H.; Su, J.-H.; Huang, C.-Y.; Dai, C.-F.; Wen, Z.-H.; Sheu, J.-H. A novel symmetric sulfur-containing biscembranoid from the Formosan soft coral Sinularia flexibilis. Tetrahedron Lett. 2010, 51, 5764-5766. 
20. Shih, H.-J.; Tseng, Y.-J.; Huang, C.-Y.; Wen, Z.-H.; Dai, C.-F.; Sheu, J.-H. Cytotoxic and anti-inflammatory diterpenoids from the Dongsha Atoll soft coral Sinularia flexibilis. Tetrahedron 2012, 68, 244-249.

21. Su, C.-C.; Wong, B.-S.; Chin, C.; Wu, Y.-J.; Su, J.-H. Oxygenated cembranoids from the soft coral Sinularia flexibilis. Int. J. Mol. Sci. 2013, 14, 4317-4325.

22. Anjaneyulu, A.S.R.; Rao, G.V.; Sagar, K.S.; Kumar, K.R.; Mohan, K.C. Sandensolide: A new dihydroxycembranolide from the soft coral, Sinularia sandensis Verseveldt of the Indian Ocean. Nat. Prod. Lett. 1995, 7, 183-190.

23. Ma, A.; Deng, Z.; van Ofwegen, L.; Bayer, M.; Proksch, P.; Lin, W. Dendronpholides A-R, cembranoid diterpenes from the Chinese soft coral Dendronephthya sp. J. Nat. Prod. 2008, 71, $1152-1160$.

24. In the in vitro anti-inflammatory bioassay, the inhibitory effects on the generation of superoxide anion and the release of elastase by activated neutrophils were used as indicators. For significant activity of pure compounds, an inhibition rate $\geq 50 \%$ is required (inhibition rate $\leq 10 \%$, not active; $20 \% \geq$ inhibition rate $\geq 10 \%$, weakly anti-inflammatory; $50 \% \geq$ inhibition rate $\geq 20 \%$, modestly anti-inflammatory).

25. Crystallographic data for the structure of (-)-sandensolide (4) have been deposited with the Cambridge Crystallographic Data Center as supplementary publication number CCDC 931762. Copies of the data can be obtained, free of charge, on application to CCDC, 12 Union Road, Cambridge CB2 1EZ, UK [Fax: +44-(0)-1223-336033 or E-Mail: deposit@ccdc.cam.ac.uk].

26. Flack, H.D. On enantiomorph-polarity estimation. Acta Crystallogr. 1983, A39, 876-881.

27. Yu, H.-P.; Hsieh, P.-W.; Chang, Y.-J.; Chung, P.-J.; Kuo, L.-M.; Hwang, T.-L. 2-(2-Fluorobenzamido)benzoate ethyl ester (EFB-1) inhibits superoxide production by human neutrophils and attenuates hemorrhagic shock-induced organ dysfunction in rats. Free Radic. Biol. Med. 2011, 50, 1737-1748.

28. Hwang, T.-L.; Wang, C.-C.; Kuo, Y.-H.; Huang, H.-C.; Wu, Y.-C.; Kuo, L.-M.; Wu, Y.-H. The hederagenin saponin SMG-1 is a natural FMLP receptor inhibitor that suppresses human neutrophil activation. Biochem. Pharmacol. 2010, 80, 1190-1200.

29. Hwang, T.-L.; Su, Y.-C.; Chang, H.-L.; Leu, Y.-L.; Chung, P.-J.; Kuo, L.-M.; Chang, Y.-J. Suppression of superoxide anion and elastase release by $\mathrm{C}_{18}$ unsaturated fatty acids in human neutrophils. J. Lipid Res. 2009, 50, 1395-1408.

30. Hwang, T.-L.; Li, G.-L.; Lan, Y.-H.; Chia, Y.-C.; Hsieh, P.-W.; Wu, Y.-H.; Wu, Y.-C. Potent inhibition of superoxide anion production in activated human neutrophils by isopedicin, a bioactive component of the Chinese medicinal herb Fissistigma oldhamii. Free Radic. Biol. Med. 2009, 46, 520-528.

31. Hwang, T.-L.; Leu, Y.-L.; Kao, S.-H.; Tang, M.-C.; Chang, H.-L. Viscolin, a new chalcone from Viscum coloratum, inhibits human neutrophil superoxide anion and elastase release via a cAMP-dependent pathway. Free Radic. Biol. Med. 2006, 41, 1433-1441.

32. Hwang, T.-L.; Yeh, S.-H.; Leu, Y.-L.; Chern, C.-Y.; Hsu, H.-C. Inhibition of superoxide anion and elastase release in human neutrophils by 3 '-isopropoxychalcone via a cAMP-dependent pathway. Br. J. Pharmacol. 2006, 148, 78-87. 
33. Hwang, T.-L.; Hung, H.-W.; Kao, S.-H.; Teng, C.-M.; Wu, C.-C.; Cheng, S.J.-S. Soluble guanylyl cyclase activator YC-1 inhibits human neutrophil functions through a cGMP-independent but cAMP-dependent pathway. Mol. Pharmacol. 2003, 64, 1419-1427.

34. Manns, D.; Hartmann, R. Echinodol: A new cembrane derivative from Echinodorus grandiflorus. Planta Med. 1993, 59, 465-466.

35. Tanaka, C.M.A.; Sarragiotto, M.H.; Zukerman-Schpector, J.; Marsaioli, A. A cembrane from Echinodorus grandiflorus. Phytochemistry 1997, 44, 1547-1549.

36. Shigemori, H.; Shimamoto, S.; Sekiguchi, M.; Ohsaki, A.; Kobayashi, J. Echinodolides A and B, new cembrane diterpenoids with an eight-membered lactone ring from the leaves of Echinodorus macrophyllus. J. Nat. Prod. 2002, 65, 82-84.

37. Shy, H.-S.; Wu, C.-L.; Paul, C.; König, W.A.; Ean, U.-J. Chemical constituents of two liverworts Metacalypogeia alternifolia and Chandonanthus hirtellus. J. Chin. Chem. Soc. 2002, 49, 593-598.

38. Garcez, F.R.; Garcez, W.S.; da Silva, A.F.G.; de Cássia Bazzo, R.; Resende, U.M. Terpenoid constituents from leaves of Guarea kunthiana. J. Braz. Chem. Soc. 2004, 15, 767-772.

39. Chen, Y.-L.; Lan, Y.-H.; Hsieh, P.-W.; Wu, C.-C.; Chen, S.-L.; Yen, C.-T.; Chang, F.-R.; Hung, W.-C.; Wu, Y.-C. Bioactive cembrane diterpenoids of Anisomeles indica. J. Nat. Prod. 2008, 71, 1207-1212.

40. Li, L.-M.; Li, G.-Y.; Pu, J.-X.; Xiao, W.-L.; Ding, L.-S.; Sun, H.-D. ent-Kaurane and cembrane diterpenoids from Isodon sculponeatus and their cytotoxicity. J. Nat. Prod. 2009, 72, 1851-1856.

41. Wang, Y.; Harrison, L.J.; Tan, B.C. Terpenoids from the liverwort Chandonanthus hirtellus. Tetrahedron 2009, 65, 4035-4043.

42. Komala, I.; Ito, T.; Nagashima, F.; Yagi, Y.; Kawahata, M.; Yamaguchi, K.; Asakawa, Y. Zierane sesquiterpene lactone, cembrane and fusicoccane diterpenoids, from the Tahitian liverwort Chandonanthus hirtellus. Phytochemistry 2010, 71, 1387-1394.

43. Asakawa, Y.; Ludwiczuk, A.; Nagashima, F. Chemical Constituents of Bryophytes: Bio- and Chemical Diversity, Biological Activity, and Chemosystematics. In Progress in the Chemistry of Organic Natural Products; Springer: Vienna, Austria, 2013; Volume 95, pp. 1-796.

44. Bonnard, I.; Jhaumeer-Laulloo, S.B.; Bontemps, N.; Banaigs, B.; Aknin, M. New lobane and cembrane diterpenes from two Comorian soft corals. Mar. Drugs 2010, 8, 359-372.

Samples Availability: Not available.

(C) 2013 by the authors; licensee MDPI, Basel, Switzerland. This article is an open access article distributed under the terms and conditions of the Creative Commons Attribution license (http://creativecommons.org/licenses/by/3.0/). 